\title{
Fitness to Transfer and/or Deport to a Foreign Country, Political and Other Pressures on the FME and The Ethical Considerations of Such Transfers
}

\author{
Robert M. Bruce-Chwatt ${ }^{\star}$ \\ MBBS (Lond.), MFTM RCPS (Glasg), DFFP, part 1 DMJ, Senior Forensic Medical Examiner (FME), Metropolitan Police, London, UK
}

\section{Migrant Broke Neck}

An illegal immigrant repeatedly slammed his head against a wall, breaking his neck in three places to avoid being deported. Amadov Nyang, a 34-years-old African, was being held in a cell at Tinsley House immigration removal centre near Gatwick. He is on a ventilator in hospital [1]. Areas of high immigrant population are ideal places for the illegal immigrant to gravitate to as he or she is less likely to stand out or be noticed by skin colour or poor or even non-existent language skills of the host country, creating ghettos of necessity, not choice. Being an illegal they will, of course, be vulnerable to threats of blackmail, coercion, prostitution, violence and resorting to crime to survive as they have no legal way of earning money. As such they are at high risk of being arrested and it is at this time that their immigrant status emerges. Illegals fear any contact with officialdom, including the NHS. The examining forensic physician is frequently faced with their considerable medical problems often including TB and HIV for which they have, as yet, sought no help. There are now many such areas in large towns in the UK with identical problems. The forensic physician is increasingly drawn into the decision of whether the prisoner is fit to detain and charge, as is more often the case, as well as whether they are fit to be deported by air having been served with a deportation order. After all the legal avenues, including the Human Rights Act, [2] have been exhausted, then under the Immigration, Asylum and Nationality Act 2006, under paragraph 10 , schedule 2 , there is authority to remove [3].

The FP/FME may remain the final hope to any further delay and this has become difficult, with serious threats of self-harm $[4,5]$ or invented symptoms. Accusations of racism or political incorrectness remain if the FMEs decision is not to the liking of the prisoner. The FP/FME may also be under pressure from the authorities to certify the prisoner or deportee fit for travel or may be contradicted in his clinical judgment by a medical colleague instructed by the lawyers acting for the detainee and provided by the s legal aid system of the relevant country. In some cases: "He who pays the piper calls the tune", perhaps?

There are a number of absolute contraindications to flying [6] and consideration should be taken of any medical equipment aboard should any in-flight problems arise $[7,8]$. This, of course, relates to persons who are not only physically and mentally fit to travel by air, but who are also willing to return to their own country and those, as in the case of the late General Augusto Pinochet, who are delighted to be returning to their own country. There are also those who are quite determined to avoid returning at all costs and, though they may not plan it that way or be aware of the risks, end with a fatal result. Fatal outcomes include Joy Gardiner in the UK in 1993, Marcus Omofuma in Vienna and Khaled Abuzarifeh flying to Cairo, Egypt from Klöten Airport, Zurich, Switzerland on March 3 1999. As a result of the latter's death, a Swiss doctor, found guilty in 2004 of negligent homicide, was sentenced to three months in prison, suspended, and also fined ChFr.50,000 (£25,000). Aamir Ageeb died in 1999 during a repatriation flight from Frankfurt-äm-Main, Germany to Khartoum,
Sudan, despite the best efforts of three doctors who happened to be on board the aircraft at the time. In October 2004 the three officers escorting him were found guilty at a court in Germany and each given nine month suspended sentences. The last death in the canton of Valais, Switzerland in 2001 was that of a Nigerian, Samson Chukwa, who was asphyxiated in his cell during a struggle with police [9]. After two deaths of illegals during transfer, the Swiss Federal Police instigated an annual one week training course for officers escorting prisoners abroad with a comprehensive medical input for such forced repatriation flights [11]. At Klöten, Zurich International airport on the $18^{\text {th }}$ March 2010, a male 29 years old Nigerian asylum seeker collapsed and die at the airport whilst be escorted after a struggle to the aircraft. The Nigerian, a convicted drug dealer who had been in Switzerland since 2005, part of the time in prison, was due to board the flight 15 others who had refused to leave the country despite expulsion orders. He had been on hunger strike for several days. The autopsy was inconclusive. This is now the third such death in Switzerland since 1999. Last year there were 43 special repatriation flights from Switzerland, deporting some 360 people, mostly to the Balkans or Africa.

Even if the flight passes off without incident, there may be accusations afterwards, as in the case of Mahomet Ismail, an Afghani, deported from London on April 29 2003, who on arrival at Kabul International Airport, publicly accused the Metropolitan police of brutality over the alleged forcible application of hand-cuffs.

On July 2, 2000 the author was asked to provide medical cover as an FP/FME for the repatriation of General Augusto Uguarte Pinochet from his residence on the Wentworth Estate, Windsor. The Home Secretary, Jack Straw, had made a decision about General Pinochet's continued 16 month detention under an extradition request from Judge Balthazar Garzon in Spain, and would be announcing it at 0800 hours on July 3,2000 . There was little doubt that he would be released.The General, 84 years old, appeared overweight, though fit and well. No formal medical examination was made or history taken, although there was a discussion with his own personal physician, a Chilean doctor. General Pinochet's release was to be on medical grounds of his "poor health" and inability to stand trial for alleged multiple murder when President of Chile. The presence of a forensic physician was possibly more as a witness and therefore token and

*Corresponding author: Robert M. Bruce-Chwatt, MBBS (Lond.), MFTM RCPS (Glasg), DFFP, part 1 DMJ, Senior Forensic Medical Examiner (FME), Metropolitan Police, London, UK, E-mail: robert@bruce-chwatt.fsnet.co.uk

Received December 13, 2010; Accepted December 29, 2010; Published December 31, 2010

Citation: Bruce-Chwatt RM (2010) Fitness to Transfer and/or Deport to a Foreign Country, Political and Other Pressures on the FME and The Ethical Considerations of Such Transfers. J Forensic Res 1:110. doi:10.4172/2157-7145.1000110

Copyright: (c) 2010 Bruce-Chwatt RM. This is an open-access article distributed under the terms of the Creative Commons Attribution License, which permits unrestricted use, distribution, and reproduction in any medium, provided the original author and source are credited. 
superfluous. Any illness that might have been found then would have appeared to be un-diplomatic, although should he become ill, the official Metropolitan police doctor, would be responsible, rather than the Chilean doctor. At 08:00 hours the Home Secretary announced, as expected, that, "on medical grounds", the General was being released. The convoy travelled together to RAF Waddington without any problem or incident and the author handed over full responsibility to his Chilean colleague at the aircraft.The General (in a wheelchair) and his entourage boarded the CAF Boeing-707, flying off to Santiago, Chile shortly thereafter. The following day, questions as to his actually being that ill, if at all, were raised by a number of newspapers and the cartoonists made this clear. A letter [10], published in The Times on March 5 2000, attempted to correct the, admittedly humorous, impression given in cartoons by Pugh and Peter Brookes below. General Pinochet was, sometime later, re-arrested by the Chilean authorities and held under house arrest pending trial. He lived another six years, suffering a major heart attack on December 3, 2006. Released the following day from house arrest, pending further judicial enquiries in Santiago, Chile, he died a week later, aged of 91 , in the ITU of a local military hospital. A subsequent autopsy gave the cause of his death as congestive cardiac failure and pulmonary oedema. It might have been said that General Pinochet died without standing trial, however justice caught up with him in another sense. Pinochet syndrome [11] mutating, in the international human rights lexicon, to the posthumous sobriquet: "Pinochet precedent", has made the world a much smaller place for the perpetrators of the worst atrocities and can be thought of as one of the most important events in international law since Nüremberg 1945-1949 [12].The Pinochet case inspired victims of abuse elsewhere, particularly in Latin America, to challenge "arrangements" of the 80 s and 90 s that had allowed perpetrators of atrocities to go unpunished. In 2005 Argentina's Supreme Court repealed immunity laws for former junta officials who now face arrest, trial and life imprisonment for their crimes during Argentina's "Dirty War" of 1976-1983 when 30,000 died. Admiral Jorge Videla's life sentence was reconfirmed on April 252007 by the Federal Court in Buenos Aires. After the UN tribunals for Yugoslavia and Rwanda, the UN established the International Criminal Court, at The Hague, to prosecute genocide, crimes against humanity and serious war crimes when national courts are unable or, more often, unwilling to do so. Charles Taylor, the former warlord in Sierra Leone is still on trial, having only just finished his sevenmonth long testimony to the ICC on February 19, 2010, stating, not surprisingly, that prosecutors have not proven their case against him. Such trials are not without stress for the accused; Slobodan Miloševi, the Serbian leader died of a heart attack in 2006 during his trial at the ICC, but Ramush Haradinaj, Serbian Prime Minister 2004-05, was acquitted [5] on April 32008.

\section{Discussion}

Along with the request for fitness to detain and interview the FP is also asked if the prisoner is fit to transfer. With prisoners now being collected at police stations and being taken directly to the airport, they are now also asked to consider their fitness to fly, often abroad, often for many hours. There are some absolute clinical contraindications to travel by commercial aircraft, not a few due to potential barotraumas (List of Clinical Criteria) and Professor Ross McFarland's aphorism that: "Those who can walk can fly", should most certainly not be taken at face value or as even correct [5].The fact that they may be unwilling to be repatriated is not strictly a medical matter, but may well affect their wellbeing, their wish to self-harm or their death during a violent arrest and struggle. The previously mentioned case of Mrs Joy Gardner, who had suffocated and died on August 1 1993, allegedly after being gagged, resulted in two Metropolitan police officers standing trial for manslaughter at the Old Bailey. Mrs Gardner, an overstayer and in the UK illegally, had arrived from Jamaica on a six-month visa in 1987. The trial resulted in not guilty verdicts on the police officers; the Coroner's inquest a verdict of misadventure. The rules then were changed, banning extradition or repatriation personnel with the Metropolitan police or the Home Office from using any type of mouth gag or positioning such as "hog-tying" below, making proper breathing difficult or even near impossible. Since this has been followed there have been no further incidents in which the person being deported has died. The latest figures from the Home Office have shown a fall by more than $25 \%$ of failed asylum seekers and their dependants removed from the UK, with

13,595 in 2007 compared with more than 18,000 in 2006 . The top five nationalities removed were Afghans, Nigerians, Serbians, Pakistanis and Turks. The majority of those removed from the UK were illegal immigrants and overstayers [13].This further extension of the responsibilities of the FME is an indication of the many complexities of the cases that they are asked to see and make decisions on, decisions that must stand the test of time, possibly in another country many weeks later, as now seen in the Ama Sumani case. Mrs Sumani was deported to Ghana despite local protests and died, two months afterwards, on March 20 2008, having been previously treated at the University Hospital of Wales at Cardiff for malignant myeloma. The case raised wide medical and social concerns and resulted in a highly critical editorial in The Lancet [14].

\section{References}

1. News The Times. 2008 February 11

2. The Human Rights Act 1998

3. The Immigration, Asylum and Nationality Act 2006

4. Norfolk GA (1998) Deaths in police custody during 1994: a retrospective analysis. J Clin Forensic Med 5: 49-54

5. International Court at The Hague.

6. Frater A (2008) Deaths in custody. BMJ 336: 845-846

7. Bruce-Chwatt R (1987) Please Doctor, am I fit to fly? Pulse 3

8. Bruce-Chwatt R (1992) Airline doctors-only medical kit. 28.

9. Tonks A (2008) Cabin fever. BMJ 336: 584-586.

10. Wüthrich A, réportage, «Le Temps », Genève, Switzerland, 2003, February 1

11. Bruce-Chwatt $R$ Sécurité médicale et physique des déportés et des extradés lors de refoulements par voie aérienne. (Medical and physical safety of deportees and those extradited, when transferred by air) Lecture for the Swiss Police Institute, Neuchâtel given annually since 2003 at police training centre, Genève, Switzerland.

12. Implications of Pinochet release. The Times 2000 March 3.

13. Black M (2006) Diagnosing Pinochet syndrome. BMJ 332: 185.

14. Jonas S (2004) Ripple Effect of the Pinochet Case. Human Rights Brief 11 36-38.

15. Home Office figures News The Times 2008 February 2724.

16. Editorial (2008) Access to health care for undocumented migrants in Europe Lancet 370: 2070 